\title{
Use of the amniotic membrane to cover the peritoneal cavity in the reconstruction of the abdominal wall with polypropylene mesh in rats
}

\section{Uso da membrana amniótica como cobertura da cavidade abdominal na reconstrução da parede com tela de polipropileno em ratos}

Rafael Calvão Barbuto'; Ivana Duval de Araujo'; Daniel de Oliveira Bonom²; luciene Simões de Assis Tafuri3; Antônio Calvão

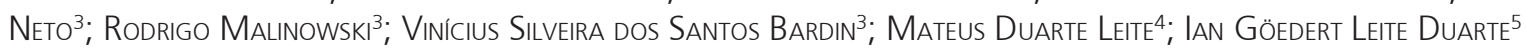

\author{
A
}

\begin{abstract}
Objective: to evaluate the efficacy of the amniotic membrane used with polypropylene mesh against the formation of adhesions and its influence on healing. Methods: twenty five female Wistar rats were anesthetized for creating a parietal defect in the anterior abdominal wall. Its correction was made with polypropylene mesh alone and associated with amniotic membrane. In the control group ( $n=11)$, the screen was inserted alone. In group $A(n=7)$ we interposed the amniotic membrane between the screen and the abdominal wall. In group B, the amniotic membrane was placed on the mesh, covering it. After seven days, the animals were euthanized for macroscopic and microscopic evaluation of healing. Results: adhesions were observed in all animals except one in the control group. Severe inflammation was observed in all animals in groups A and B and in three of the control group, with significant difference between them $(A$ and $B$ with $p=0.01$ ). Pronounced angiogenic activity was noted in one animal in the control group, six in group $A$ and four in group $B$, with a significant difference between the control group and group $A(p=0.002)$ and group $B(p=0.05)$. The scar collagen was predominantly mature, except in five animals of the control group, with significant difference between the control group and group A $(p=0.05)$ and group $B(p=0.05)$. Conclusion: The amniotic membrane did not alter the formation of adhesions in the first postoperative week. There were also pronounced inflammation, high angiogenic activity and predominance of mature collagen fibers, regardless of the anatomical plane that it was inserted in.
\end{abstract}

Key words: Tissue Adhesions. Amnion. Abdominal Wall. Rats. Collagen.

\section{INTRODUCTION}

T he incisional hernia is a common condition. Lima' described that Kozoll and McVay reported incidence of incisional hernia in $5.7 \%$ of laparostomies performed in private hospitals and $11.1 \%$ in public hospitals.

Currently, the treatment of incisional hernias, as well as the repair of abdominal wall defects with loss of aponeurotic tissue, has been made with the use of polypropylene meshes. The polypropylene prosthesis can be inserted both in the above-aponeurotic and the subaponeurotic positions, and in the latter option it can be allocated in the pre-peritoneal or intra-abdominal region.

Studies have shown that the best position for the placement of the polypropylene mesh is in the pre-peritoneal subaponeurotic position. However, in many situations, such as the giant hernias or those multi-relapsed, the large wall resections, such as tumors, or in the loss of large amounts of tissue wall, as in trauma, it is not possible to cover the prosthesis with the peritoneum. In these cases, the polypropylene mesh is placed in direct contact with the organs and intra-abdominal tissues, resulting in the onset of adhesions and consequent intestinal obstructionor fistula. Many techniques and biological and synthetic materialshave been used to minimize these changes, such as coverage of the abdominal cavity with omentum, bovine pericardium prosthesis with organic and inorganic component, among others, but without ideal results.

Lately, some authors have suggested the use of amniotic membrane in the repair of tissue defects. Since the first half of the last century, some researchers have been studying the use of amniotic membrane in the reconstitution of tissue lesions, especially the skin, as recommended by Fontenla et al. ${ }^{2}$. Davis, in 1910, announced the intention of injecting amniotic sac fragments in order favoring the open wound granulation, and

1. Department of Surgery, Faculty of Medicine, Federal University of Minas Gerais (FM/UFMG), Belo Horizonte, Minas Gerais State, Brazil; 2 . Instituto Mário Penna, Belo Horizonte, Minas Gerais State, Brazil; 3. Faculty of Medical Sciences, Universidade José do Rosário Vellano (Unifenas), Belo Horizonte, Minas Gerais State - MG, Brazil; 4. Faculty of Medicine, Centro Universitário de Belo Horizonte (UNIBH), Minas Gerais State - MG, Brazil; 5. STK Núcleo de Cirurgia Plástica, Belo Horizonte, Minas Gerais State - MG, Brazil. 
subsequently in eye tissues ${ }^{3}$. Fontenla et al. ${ }^{2}$ and del Campo et al. ${ }^{4}$, report that in 1995, Kim and Tseng reintroduced the use of amniotic membrane in the treatment of ocular lesions, ophthalmology being the specialty where more research is made on the use of amniotic membrane today. There are other studies on its use for burns $s^{5,6}$, varicose ulcers ${ }^{5,7}$, neovagina reconstruction ${ }^{5,8}$, urinary bladder ${ }^{5,9}$, nerve damage ${ }^{5,10}$, mouth sores $s^{5,11}$, adhesions control and early healing of peritoneal lesions ${ }^{5,12}$, among others.

The study of clinical use of amniotic membrane is of increasing importance due to its low antigenicity, antimicrobial activity, ability to decrease exudate and adhesions, to accelerate epithelization, reducing the local pain, actingas a substrate for tissue growth, among many other actions 5 .

Based on literature data, it is possible to imagine that, due to its properties that favor the restructuring of the damaged portions of the tissue, the amniotic membrane could be used as biological coverage of the abdominal cavity in the abdominal wall reconstruction using polypropylene prosthesis, representing an alternative in cases where there is no viable peritoneum. Its action at different stages of the healing process (inflammation, proliferation and maturation) could bring beneficial effects, such as decreased adhesions and reconstitution of the peritoneum ${ }^{13}$.

This study aimed to evaluate the efficacy of the amniotic membrane associated with a polypropylene mesh and its influence on adhesion formation and wound healing.

\section{METHODS}

This study was approved by the Ethicsin Research Committee of the Universidade José do Rosário Vellano (UNIFENAS) under 25A/2008 number and developed in accordance with the rules of the Brazilian College of Animal Experimentation.

We used 25 female Wistar rats, weighing $400 \mathrm{~g}$ and about six months old. The animals were from the Central Animal Laboratory of the Universidade Federal de Minas Gerais and were kept in the animal house of the Universidade José do Rosário Vellano, Bonaventure Campus, Belo Horizonte. Throughout the study, animals were subjected to natural conditions in their own cages, up to five per cage and fed standard chow and water ad libitum.

The animals were randomly divided into three groups: control group $(n=11)$ : animals with defect in the abdominal wall repaired with polypropylene mesh in intraabdominal position. Group A ( $n=7)$ : animals with defects in the abdominal wall repaired with polypropylene mesh in intra-abdominal position and amniotic membrane interposed between the implant and the abdominal wall. Group B $(n=7)$ : Animals with defects in the abdominal wall repaired with polypropylene mesh in intra-abdominal position and amniotic membrane covering it.
The preparation of the amniotic membrane ${ }^{5}$ occurred in the Research Laboratory of the Faculty of Medicine, Universidade Federal de Minas Gerais (FM/ UFMG). It was obtained from an adult femalerabbit from the UFMG Veterinary School. The rabbit was surgically subjected to pregnancy interruption, and from each fetus the placenta was collected along with the fetal membranes. The amniotic membranes were isolated from other fetal membranes and placed in metal trays containing sterile $0.9 \%$ saline solution in sufficient quantity to cover them, in order to wash the tissue, removing clots. This solution was exchanged six times, until the membrane was clean. After washing, the amniotic membranes were immersed in a Becker flask containing $500 \mathrm{ml}$ of phosphate-buffered saline (SSC), pH 7.2, containing $0.15 \mathrm{M} / \mathrm{mL}$ sodium chloride and $6.5 \mathrm{mM} / \mathrm{mL}$ potassium phosphate (Buffer PBS®- Laborclin Ltda., Pinhais, Brazil) for 40 minutes. Thereafter, each membrane was carefully laid on a sterile nitrocellulose paper (Hybond - ECL®, Amersham Pharmacia Biotech, Buckhingham shire, England) with a pore size of 0.2 microns thickness and dimensions $20 \mathrm{~cm} \times 20 \mathrm{~cm}$. The stromal side of the membrane was placed in contact with the nitrocellulose paper and then the excess paper was cut, forming strips of $10 \mathrm{~cm} \times 8 \mathrm{~cm}$, which were stored in sterile plastic containers. This material was completely immersed in a $98 \%$ glycerol solution and kept refrigerated at $8^{\circ} \mathrm{C}$ until the date of their use, which occurred two weeks after preparation and conservation.

The creation of defects in the abdominal wall was performed using clean technique, but not aseptic. The animals were anesthetized with intraperitoneal injection of ketamine hydrochloride solution $(50 \mathrm{mg} / \mathrm{kg}$ ) and xylazine $(8 \mathrm{mg} / \mathrm{kg})$. After anesthesia weincised the skin and subcutaneous tissue and created a defect in the abdominal wall in the mesogastrium region, through the resection of a $1.0 \mathrm{~cm}$ diameter fragment of muscle-aponeurotic layer and the parietal peritoneum ${ }^{13}$.

The abdominal defect was corrected using a polypropylene mesh of approximately $2.7 \mathrm{~cm} \times 4.0 \mathrm{~cm}$ (Marlex mesh, CR BARD, Salt Lake City, UT). In the control group the prosthesis was inserted into the intra-abdominal position, spanning the parietal defect, with its major axis in the longitudinal direction, and sutured to the abdominal wall with simple stitches with 5-0polyglactin in the four corners of the prosthesis. The intestines were protected with an omentum coverage in an attempt to minimize contact with the prosthesis. Then we proceeded to the synthesis of the skin and subcutaneous tissue with 2-0 chromic catgut running suture and finally wound antisepsis with $10 \%$ aqueous povidone-iodine (PVP). In the other groups, the surgical technique for the treatment of the defect was similar; in group $A$, we inserted the amniotic membrane between the prosthesis and the abdominal wall; and in group $B$, the amniotic membrane was positioned underneath the mesh, creating acover on its abdominal surface (Figure 1). 
In the first 12 hours after surgery the animals were fed with oral $20 \%$ glucose solution and, from there, water and standard rodent chow ad libitum. For analgesia, all animals received nalbuphine hydrochloride injection 3mg/ $\mathrm{kg} /$ day (12/12 hours) within the first 48 postoperative hours. The first dose was taken at surgery due to the synergistic anesthetic effect.

The macroscopic assessment occurred seven days after the abdominal walldefect correction. The animals were again anesthetized and subjected to a U-shaped laparotomy around the sides and bottom edges of the prosthesis. Then we carried out the inventory of the peritoneal cavity in order to observe the presence of fistulas, abscesses and adhesions between the implant and the abdominal contents. Adhesions, when present, were classified according to the force applied to loosen the attached structures like the following: Grade I (loose) - easily detaching at manipulation; Grade II (firm) - easily detaching atstructurestraction; and Grade III (very firm) - not detaching easily at structures traction. Results were recorded in an appropriate protocol for statistical evaluation.

Biopsy specimens were collected spanning the full thickness of the abdominal wall and the polypropylene mesh that was in direct contact (Control group), and the amniotic tissue, in the case of animals in which the membrane wasimplanted (groups A and B).

The specimens preserved in $10 \%$ formalin were embedded in paraffin, submitted to section of 4,0im thick, mounted on glass slides and stained with hematoxylin-eosin. The tissue sections were included in the slide, so as to meet all the layers of the abdominal wall, in addition to the polypropylene mesh, and amniotic membrane (in the case of groups $A$ and $B$ ). The slides were analyzed at $40 x$ magnification by a single pathologist blinded to the study groups, to evaluate the following parameters:Inflammatory reaction -analyzed the presence or absence of inflammatory activity and, in the presence of inflammation, this was classified as mild, moderate or severe;Predominant inflammatory infiltrate type - the fields were evaluated in order to classify the inflammatory infiltrate in acute or chronic according to the predominant cell type: polymorphonuclear, mononuclear or mixed; Granulation changes - search for common giants inflammatory cells, common in the inflammatory processes stimulated by substances or allergens agents (foreign body reaction); Angiogenesis search for neovascularization and, when present, classified as mild, moderate or severe, according to the activity and amount of angioblasts and other cells associated with angiogenesis; Proportion macrophage/fibroblast - analyzed the prevalence of macrophages or fibroblasts in the scar tissue, by counting these cells; Proportion of collagen fibers - the type of collagen fiber (immature or mature) predominantly deposited in the scar matrix. All results were recorded in their own protocols for subsequent statistical evaluation .

At the end of the collection of the abdominal wall biopsy material, animals, still under anesthesia, were killed by exsanguination via the abdominal aorta section on the seventh day ${ }^{14}$.

The collected data were analyzed, the differences were considered significant at $p<0.05$. Quantitative variables were compared using the Kruskal-Wallis test and the qualitative variables, by Fischer test.

\section{RESULTS}

No animal had intra-abdominal abscess. Most animals had adhesions between the polypropylene prosthesis and the omentum and, more rarely, the intesti-

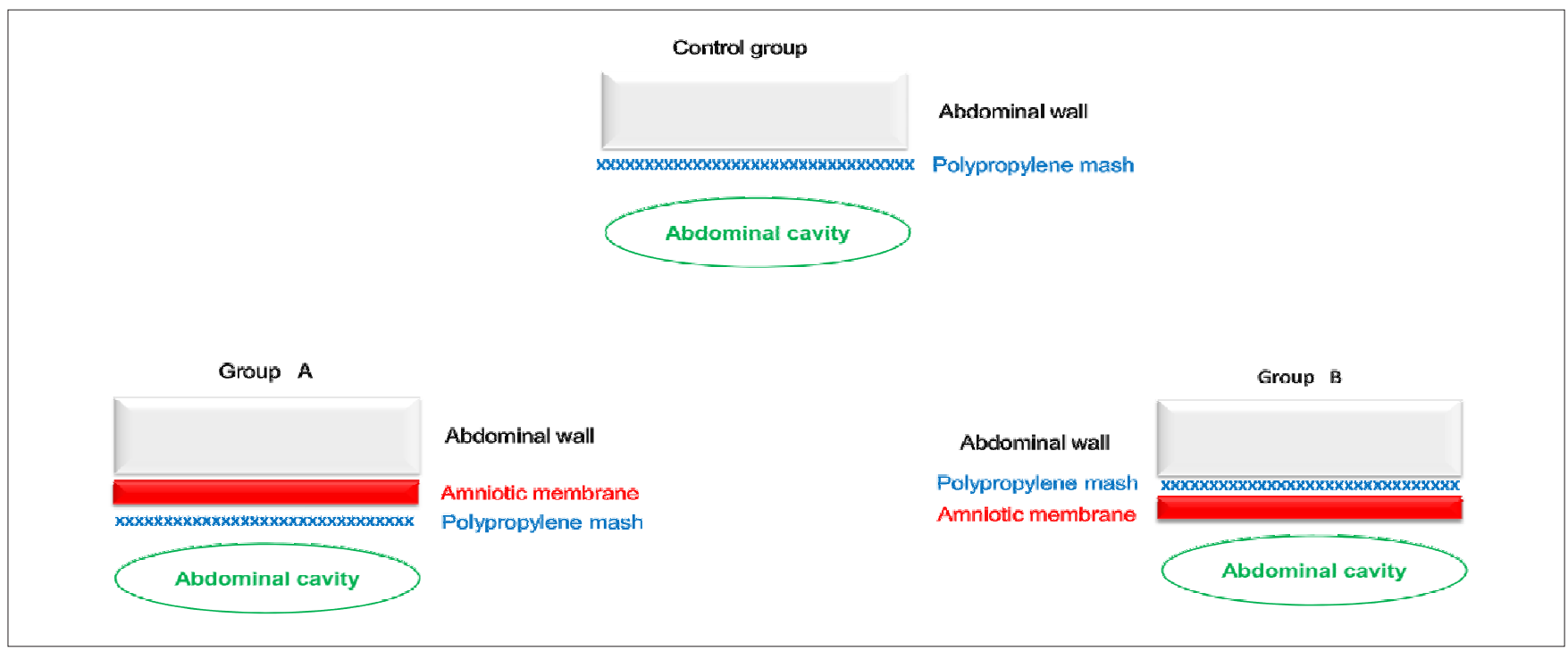

Figure 1 - Schematic drawing showing the attachment position of the polypropylene prosthesis and insertion of amniotic membrane in the study groups with respect to the wall and the abdominal cavity. 
nal loops, but one Animal in the Control group. There was no significant difference when the groups were compared. Similarly, there was no difference between groups when comparing the degree of adhesions (Table 1).

There was inflammation in all animals, except for one animal of the Control group. The intensity of the inflammatory process was marked in all animals of groups $A$ and $B$, with the difference whencompared with the control group, both with $\mathrm{p}=0.01$ (Figure 2).

There was a predominance of mononuclear infiltrate over polymorphonuclear or mixed infiltrates, but no difference when each type of cell infiltrate was compared between groups. Angiogenesis was present in all animals, being classified as sharp predominantly in groups $A$ and $B$, with a significant difference when compared with the control group, with $p=0.002$ and $p=0.05$, respectively (Figure 2 ).

There was a predominance of fibroblasts overmacrophages in all groups, being more intense in groups $A$ and $B$, but without significant differences when compared to fibroblasts from each group together. Collagens deposited in the wound areas were mainly mature fibers, with the exception of five animals of the control group, in which prevailed immature collagen fibers. There was statistical difference in the predominance of immature collagen fibers in the control group compared with groups $A(p=0.05)$ and $B(p=0.05)$, respectively (Table 2 , Figure 3$)$.

\section{DISCUSSION}

The use of polypropylene mesh in various abdominal wall defects is common'. In our country, in dire financial constraints for public health sustainability, the search for new therapeutic alternatives, associated or isolated, is very important. Amniotic membrane obtained from the placenta ${ }^{14}$ is a tissue rich in stem cells. It can be used in its fresh form, after processing, or conserved form and maintained in stock solution. In fresh form, pluripotent cells multiply rapidly, forming a tissue similar to those around it, but there is the drawback of the short time to use, since it deteriorates rapidly.
The conservation of amniotic membrane in stock solution increases its usage time. However, some studies have reported the loss of part of the living tissue, the material preserved retaining cells and growth factors sufficient to possibly stimulate healing and accelerate the repair process tissue ${ }^{15,16}$.

In general, adhesions arise from any tissue damage in the first week after injury ${ }^{17,18}$. The healing time or termination of that cell proliferation is dependent on the extent of the lesion and the healing process leads to migration of fibroblasts, macrophages and giant cells. Fibroblasts promote the initial deposit of fibrin and collagen ${ }^{18}$. The higher tissue injury, the more increased collagen and fibrindeposition, making the peritoneal fibrinolysis and increasing the adhesive capacity of the wound line, progressing to the formation of adhesions ${ }^{17,18}$.

In this study, we used thepreserved amniotic membrane and the observation time was a week after the initial tissue injury. The presence of the amniotic membrane

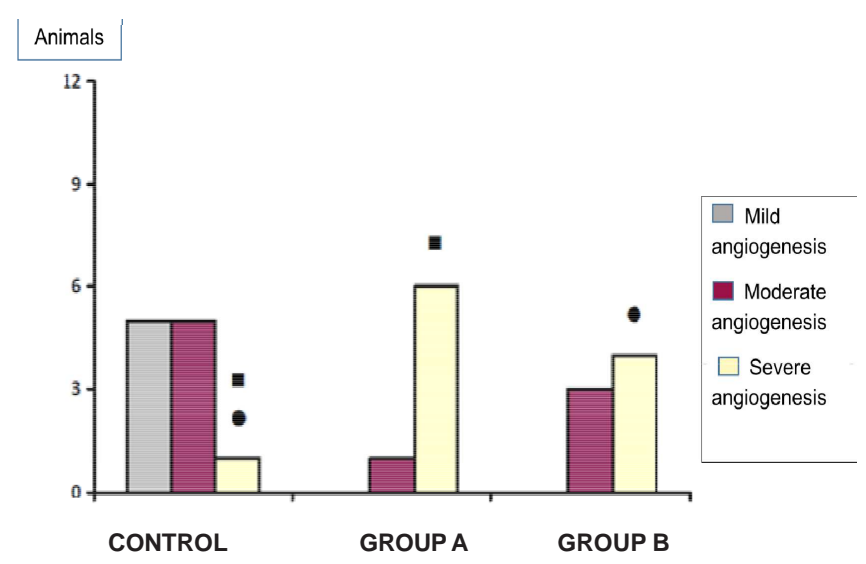

Figure 2 - Wistar rats with mild angiogenesis activity, moderate or severe scarring in the region of abdominal wall defects corrected with polypropylene mesh use (Control) associated with amniotic membrane in the prosthesis surface region (A) or deep (B).

- $p=0.002 \quad 0 p=0.05$

Table 1 - Evaluation of macroscopic parameters of the abdominal cavity of rats after treatment of abdominal defect with use of polypropylene prosthesis, with or without the use of amniotic membrane.

Parameter studied

The study $(n=07)$

Control $(n=11)$

\begin{tabular}{lrr} 
& N & \% \\
\hline Adhesions & 10 & 91 \\
Grade I Adhesions & 03 & 27.3 \\
Grade II Adhesions & 06 & 54.6 \\
Grade III Adhesions & 01 & 9.1 \\
Abscesses & 0 & 0
\end{tabular}

Group

$p$ value

B study $(n=07)$

\begin{tabular}{rrrrr}
$\mathbf{N}$ & $\%$ & $\mathbf{N}$ & $\%$ & \\
07 & 100 & 07 & 100 & $\mathrm{~ns}$ \\
03 & 43.0 & 05 & 71.5 & $\mathrm{~ns}$ \\
02 & 28.5 & 02 & 28.5 & $\mathrm{~ns}$ \\
02 & 28.5 & 0 & 0 & $\mathrm{~ns}$ \\
0 & 0 & 0 & 0 & $\mathrm{~ns}$ \\
\hline
\end{tabular}


did not change the formation of adhesions between the polypropylene mesh and the peritoneal content. This may be due to the short time of observation. Despite the healing stimulus and the formation covering tissue on the inserted polypropylene mesh, there wasprobably not enough time for this tissueto organize, thus allowing the adhesion between the prosthesis and the intra-abdominal tissues.

Angiogenesis occurred significantly in animals where the amniotic membrane was inserted, indicating the likely presence of proinflammatory substances in the conserved membrane. In addition, the amniotic membrane changed the type of collagen fibers found in the repair process.

The predominance of mature collagen fibers was observed in all animals in which the membrane was inserted, which did not occur in other animals. This demonstrates that the presence of the membrane accelerates the healing process with mature repair tissue formation, already at the early stage of tissue repair.

The association of the amniotic membrane with the polypropylene mesh in the treatment of abdominal wall defects of Wistar rats did not alter the formation of adhesions after the first week of operation. However, the amniotic membrane was associated with a marked increased

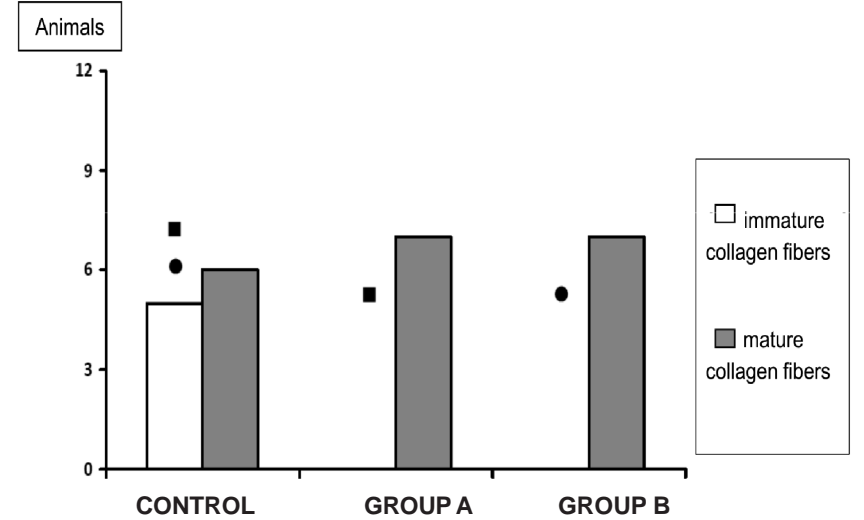

Figure 3 - Wistar rats with a predominance of immature or mature collagen fibers in scar region of abdominal wall defects corrected with polypropylene mesh use (Control) associated with amniotic membrane in the prosthesis surface region $(A)$ or deep $(B)$

inflammation and angiogenesis activity and the predominance of mature collagen fibers, regardless of the anatomical plane in which it was inserted, accelerating healing.

Table 2 - Evaluation of microscopic parameters of the abdominal wall of rats subjected to treatment of abdominal defect with use of polypropylene mesh associated or not to amniotic membrane.

\begin{tabular}{|c|c|c|c|c|c|c|c|c|}
\hline \multirow[t]{3}{*}{ Study parameter } & & \multicolumn{6}{|c|}{ Group } & \multirow[t]{3}{*}{$p$ value } \\
\hline & & \multicolumn{2}{|c|}{ Control $(n=11)$} & \multicolumn{2}{|c|}{ A study $(n=07)$} & \multicolumn{2}{|c|}{ B study $(n=07)$} & \\
\hline & & $\mathrm{N}$ & $\%$ & $\mathrm{~N}$ & $\%$ & $\mathrm{~N}$ & $\%$ & \\
\hline \multirow[t]{3}{*}{ Inflammation Degree* } & Take & 0 & 0 & 0 & 0 & 0 & 0 & \\
\hline & Moderate & 07 & 63.6 & 0 & 0 & 0 & 0 & $a=0.01$ \\
\hline & Sharp & $03^{\mathrm{a}, \mathrm{b}}$ & 27.3 & 07th & 100 & $07^{b}$ & 100 & $b=0.01$ \\
\hline \multirow[t]{3}{*}{ Type of inflammatory infiltrate } & PMN & 0 & 0 & 0 & 0 & 0 & 0 & \\
\hline & Mono & 09 & 81.8 & 07 & 100 & 06 & 85.7 & NS \\
\hline & Mixed & 02 & 18.2 & 0 & 0 & 01 & 14.3 & \\
\hline \multirow[t]{3}{*}{ Activity of angiogenesis } & Mild & 05 & 45.4 & 0 & 0 & 0 & 0 & \\
\hline & Moderate & 05 & 45.4 & 01 & 14.3 & 03 & 42.9 & $c=0.002$ \\
\hline & Intense & $01^{(e),(f)}$ & 9.2 & $06^{c}$ & 85.7 & $04^{d}$ & 57.1 & $d=0.05$ \\
\hline \multirow[t]{2}{*}{ Fibro/macro Ratio** } & Fibroblast & 07 & 63.6 & 07 & 100 & 07 & 100 & \\
\hline & Macrophage & 04 & 46.4 & 0 & 0 & 0 & 0 & NS \\
\hline \multirow[t]{2}{*}{ Collagen fibers } & Immature & $05^{(e),(f)}$ & 54.6 & $0^{\text {and }}$ & 0 & $0^{f}$ & 0 & $e=0.05$ \\
\hline & Mature & 06 & 45.4 & 07 & 100 & 07 & 100 & $f=0.05$ \\
\hline
\end{tabular}

* In one Control Group animal, the intensity of inflammation has not been classified.

* * Ratio between Fibroblasts and Macrophages. 
Objetivo: avaliar a eficácia da membrana amniótica usada com tela de polipropileno contra a formação de aderências e sua influência na cicatrização. Métodos: vinte e cinco ratas Wistar foram anestesiadas para criação de um defeito parietal na parede abdominal anterior. Sua correção foi feita com tela de polipropileno isolada e associada à membrana amniótica. No grupo Controle $(n=11)$, a tela foi inserida isoladamente intra-abdominal. No grupo $A(n=7)$, interpôs-se a membrana amniótica entre a tela e a parede abdominal. No grupo B, a membrana amniótica foi colocada sobre a tela, recobrindo-a. Após sete dias, os animais foram eutanasiados para avaliação macroscópica e microscópica da cicatrização. Resultados: aderências foram observadas em todos os animais, exceto em um do grupo Controle. Inflamação acentuada foi observada em todos os animais dos grupos $A$ e $B$ e em três do grupo Controle, com diferença significativa entre eles ( $A$ e $B$ com $p=0,01$ ). Acentuada atividade angiogênica foi notada em um animal do grupo Controle, seis do grupo $A$ e quatro do grupo $B$, com diferença significativa entre o grupo Controle e os grupos $A$ $(p=0,002)$ e $B(p=0,05)$. O colágeno cicatricial foi predominantemente maduro, exceto em cinco animais do grupo Controle, com diferença significativa entre o grupo Controle e os grupos $A(p=0,05)$ e $B(p=0,05)$. Conclusão: a presença da membrana amniótica não alterou a formação de aderências na primeira semana de pós-operatório. Associou-se à inflamação acentuada, elevada atividade angiogênica e predomínio de fibras colágenas maduras, independente do plano anatômico em que foi inserida.

Descritores: Aderências Teciduais. Membrana Amniótica. Parede Abdominal. Ratos. Colágeno.

\section{REFERENCES}

1. Lima JM. Tratamento cirúrgico das hérnias incisionais: experiência pessoal usando a malha de polipropileno monofilamentar-márlex. Rev Col Bras Cir. 2002;29(2):78-82.

2. Fontenla JR, Vázquez X, Díaz D, Gatell J, Pita D. Membrana amniótica. Características, efectos y aplicaciones em oftalmologia. Jano. 2003;64(1465):53-68.

3. Meller D, Pauklin M, Thomasen $H$, Westekemper $H$, Steuhl KP. Amniotic membrane transplantation in the human eye. Dtsch Arztebi Int. 2011;108(14):243-8.

4. del Campo Z, Gris O. Aplicaciones de la membrana amniótica en patologia ocular. Annals d'Oftalmologia. 2002;10(3):128-41.

5. Duarte IGL, Durval-Araújo I. Amniotic membrane as a biological dressing in infected wound healing in rabbits. Acta Cir Bras. 2014;29(5):334-9.

6. Singh R, Chacharkar MP. Dried gamma-irradiated amniotic membrane as dressing in burn wound care. J Tissue Viability. 2011;20(2):49-54

7. Singh R, Chouhan US, Purohit S, Gupta P, Kumar P, Kumar A, et al. Radiation processed amniotic membranes in the treatment of non-healing ulcers of different etiologies. Cell Tissue Bank. 2004;5(2):129-34

8. Carvalho BR, Reis RM, Moura MD, Lara LAS, Nogueira AA, Ferriani RA. Neovaginoplastia com membrana amniótica na síndrome de Mayer-Rokitansky-Küster-Hauser. Rev Bras Ginecol Obstet. 2007;29(12):619-24.

9. Fishman IJ, Flores FN, Scott FB, Spjut HJ, Morrow B. Use of fresh placental membranes for bladder reconstruction. J Urol. 1987;138(5):1291-4.

10. Hasegawa M, Fujisawa $H$, Hayashi $Y$, Yamashita J. Autologous amnion graft for repair of myelomeningocele: technical note and clinical implication. J Clin Neurosci. 2004;11(4):408-11.

11. Kesting MR, Loeffelbein DJ, Classen M, Slotta-Huspenina J, Hasler RJ, Jacobsen F, et al. Repair of oronasal fistulas with human amniotic membrane in minipigs. Br J Oral Maxillofac Surg. 2010;48(2):1315 .
12. Ozeren S, Corakci A, Erik A, Yûcesoy G, Yûcesoy I, Karabacak O. The effects of human membrane and fibrin sealant in the prevention of postoperative adhesion formation in the rabbit ovary model. Aust N Z J Obstet Gynaecol. 1998;38(2):207-9.

13. Tsuis $\mathrm{S}$, Ellis $\mathrm{H}$. Healing of abdominal incisional hernia in infant rats. Br J Surg. 1991;78(8):927-9.

14. Kesting MR, Wolff KD, Mücke T, Demtroeder C, Kreutzer K, Schulte $M$, et al. A bioartificial surgical patch from multilayered human amniotic membrane-In vivo investigations in a rat model. J Biomed Mater Res B Appl Biomater. 2009;90(2):930-8.

15. Paggiaro AO, Mathor MB, Carvalho VF, Polo E, Alessi MS, Herson $\mathrm{MR}$, et al. Estabelecimento de protocolo de glicerolização de membranas amnióticas para uso como curativo biológico. Rev Bras Queimaduras. 2010;9(1):2-6.

16. Hennerbichler S, Reichl B, Pleiner D, Gabriel C, Eibl J, Redl H. The influence of various storage conditions on cells viability in amniotic membrane. Cell Tessue Bank. 2007;8(1):1-8.

17. Palma MLM, Foz Filho RPP. Aderências intra-abdominais em equinos. Rev Educ Contin CRMV-SP. 2005;8(2):123-34.

18. Diogo-Filho A, Lazarini BCM, Vieira-Junyor F, Silva GJ, Gomes HL. Avaliação daderências pós-oopertórioas em ratos submetidos à peritoniostomia com tela de polipropileno associada à nitrofurazona. Arq Gastroenterol. 2004;41(4):245-9.

Received 28/02/2014

Accepted for publication 02/05/2014

Conflict of interest: none

Source of funding: none

Address for correspondence:

lan GöedertLeite Duarte

E-mail: iangduarte@gmail.com 